\title{
Business as a Pivotal Actor in the Politics of Training Reform: Insights from the Case of Germany
}

\author{
Marius R. Busemeyer
}

\begin{abstract}
Often admired by international observers, the German dual training system has come under pressure in recent years because of a persistent lack in training slots for young people. The article addresses the question of how policy makers have reacted to the problems in the training market. Particular attention is paid to the formation of politico-economic coalitions between state actors, business representatives and unions. On the basis of three case studies of recent reforms (or reform attempts), we identify two types of cross-class coalitions: a conservative coalition that aims at maintaining the status quo of the firm-based training regime and a segmentalist coalition promoting the gradual transformation of the system towards a less collective and more firm-centred variety. In both kinds of politico-economic coalitions, business actors play a pivotal role. The reason for the privileged position of business in the politics of training reform is, I argue, a politically constructed dependency of the state and unions on the continued co-operation of business in the provision of training slots. In the conclusion, I discuss the implications of my findings for the debate on the dualization of co-ordinated market economies.
\end{abstract}

\section{Introduction: motivation and research question}

The German vocational training system has long been regarded as a successful model because it traditionally combined low levels of youth unemployment with a strong competitiveness of German firms in 'diversified quality production' (Streeck 1992; see also Crouch et al. 1999; Culpepper 1999; Finegold and Soskice 1988; Green 2001). In recent years, however, the German vocational training system has come under pressure (Busemeyer 2009; Culpepper and Thelen 2008; Thelen 2007). The number of youth in need of an apprenticeship place (commonly referred to as the 'demand') first began to outstrip the

Marius R. Busemeyer is at the University of Konstanz. 
number of training slots offered by firms (the 'supply') in the 1980s, and this mismatch has intensified over the years (Busemeyer 2009: 28-41). The official figure of unsuccessful apprenticeship applicants (the difference between demand and supply) remained quite low, but it severely underestimated the true extent of the lack of training places (Ulrich 2006). The reason is that a large share of young people who fail to secure a training slot with an employer enter the so-called 'transition system' (Übergangssystem), although they would have preferred to start a regular apprenticeship. The transition system is a complex arrangement of more or less co-ordinated training and labour market instruments (Baethge et al.2007), whose only commonality is that they do not lead to certified vocational qualifications.

To put some numbers on these developments: the number of new apprenticeship contracts per year has fluctuated around 600,000 since the early 1990s. The number of new entrants into the transition system, however, has increased from roughly 280,000 to more than 400,000 (Busemeyer 2009: 29). At the height of the crisis in the early 2000s, the share of new entries into the transition system was actually larger than the share of entries into the dual training system (Autorengruppe BIBB and Bertelsmannstiftung 2011: 7). Of course, a significant share of youth in the transition system eventually manages to secure a regular training slot (Beicht 2009). Nevertheless, Ulrich (2006) estimates that in the mid-2000s, 140,000-200,000 more training slots would have been needed each year to meet the demand, that is, roughly one-third of the actual supply.

The exact causes of these developments are hotly debated among experts and policy makers. Commonly found explanations are structural changes in the economy, the aftermath of German reunification, and changes in the patterns of educational attainment and participation (see Busemeyer 2009: 62-77 for a more detailed discussion). Some critics point to the difficulty of adopting a training system rooted in manufacturing to the needs of a service and knowledge economy (Anderson and Hassel 2007; Culpepper and Thelen 2008), as evidenced by the lower willingness of firms in the service sectors to offer training. Wagner (1999) explained the partial retreat of firms from training with the rising costs associated with increases in apprenticeship pay. A related argument is that the forces of economic globalization have increased the sensitivity of firms towards the costs of apprenticeship. Employers relate the secular decline of training slots to the increasing deficiencies of young school leavers in terms of basic skills (both academic and social), the lack of vocational orientation in general schools as well as the underfunding of vocational schools. Unions, in turn, blame the employers' lack of commitment to the training system (DGB 2006).

The research question of this article, however, is not to explain changes on the apprenticeship market or the training system as such but to document and eventually explain the reaction of policy makers and other relevant stakeholders to the crisis on the apprenticeship training market. In particular, I am interested in how coalitions between different groups of actors (government, business and unions) form and how they influence policy change. 
The remainder of the article is structured as follows: the next section first discusses conventional approaches to the study of policy change in contemporary political economy: power resource theory and cross-class coalitions. This is followed by a more detailed account of the new perspective developed in this article, which highlights the role of business as a pivotal actor in the politics of training reform. Next, I present empirical evidence in the form of three case studies of recent reform projects in the field of German vocational training policy. The final section concludes by discussing the impact of recent reforms on the apprenticeship market as well as implications of the findings beyond the case of German vocational training.

\section{The politics of institutional change in contemporary political economies}

\section{Conventional Approaches}

In the growing literature on policy and institutional change in contemporary political economies, two theoretical perspectives can be distinguished that provide concrete expectations with regard to the dominant patterns in the formation of politico-economic coalitions.

The first and the older of the two perspectives mentioned above is power resource theory (Bradley et al. 2003; Korpi 1983; Stephens 1979), which regards institutions (and policies) as the outcomes of power struggles between capital and labour. The political power of the left is considered to be the decisive factor driving the expansion of welfare states and the 'pacification' of capitalism in the form of corporatist institutions (Rothstein 1987). This political power strongly depends on the presence of a united workingclass movement, that is, a strong alliance between trade unions and the social democratic parties as representatives of the working class within parliaments (Rothstein 1987: 306). The decline of traditionally supportive milieus in the working class has, of course, forced social democratic parties to appeal to new voting groups in the middle class (Kitschelt 1999), often putting strain on the traditional alliance between unions and leftist parties. Nevertheless, the central tenet of new scholarship in the tradition of power resource theory remains that the joint effect of strong unions and leftist government on the provision of working-class-friendly policies, for example, high levels of redistribution, is much stronger than the separate effects (Bradley et al. 2003: 226).

If we apply this perspective to the politics of vocational training reform in Germany, we would expect to see a coalition of trade unions and leftist parties (Social Democrats and Greens) against a coalition of rightist parties (Christian Democrats and the liberal Free Democrats) and representatives of business. This kind of confrontational coalitional pattern was in fact observed in the 1970s, when the government led by the Social Democrats (at that time in coalition with the Free Democrats) pushed forward with an ambitious reform agenda that would have significantly extended the role of the state in the German vocational training regime. These reforms were thoroughly opposed by the opposition party, the Christian Democrats, in 
alliance with business representatives from both the crafts sector and large enterprises. The crucial issue in this conflict was the balance between the need to create a sufficient number of high-quality training places, on the one hand, and the autonomy of firms in organizing the content and implementation of training ordinances, on the other.

When the Social Democrats came into power in 1998, a reasonable expectation was that the problem of a structural lack of training slots would be addressed more forcefully than it had been when the Christian Democrats were in power. The pressure on the training market had been building over the course of the 1990s. Also, employers' associations had lost a significant share of their membership after German reunification, in particular smaller firms in East Germany (Silvia and Schroeder 2007). With business power in decline, problem pressure mounting and Social Democrats in charge, there was an expectation that major reforms in vocational training were imminent. According to power resource theory, then, the change in government in 1998 could be expected to have led to a re-emergence of the old cleavages from the 1970s and to potentially major reforms in the training system.

Rooted in the Varieties of Capitalism (VoC) school of thought, the second theoretical perspective emphasizes the importance of cross-class coalitions between unions and employers as stabilizing factors in co-ordinated market economies (passim in Cusack et al. 2007; Hall and Soskice 2001; Iversen 2005). In contrast to power resource theory, this literature argues that the institutions of co-ordinated market economies provide concrete economic benefits for both labour and business, and are thus supported by actors on the two sides. The issue of skill formation is very prominent in the $\mathrm{VoC}$ school of thought. In fact, joint investments in (co-)specific human capital assets are identified as the foundation for the formation of cross-class coalitions (Cusack et al. 2007; Estévez-Abe et al. 2001). More recent (and more critical) contributions point out that these cross-class coalitions have a tendency to privilege the interests of labour market insiders over those of outsiders, contributing to a process of dualization in welfare state and labour market policies (King and Rueda 2008; Palier and Thelen 2010).

The application of cross-class coalition theories to the concrete subject of German vocational training politics leads to different predictions than in the case of power resource theory. First of all, these theories would expect cross-class coalitions between unions and employers to be the dominant coalitional pattern. Second, major reforms would seem unlikely, either because both business and labour do not see the need for large-scale reforms because they are already quite satisfied with the performance of the system or because actors on the periphery of the cross-class coalitions (such as small firms in the case of business, labour market outsiders in the case of labour) are not powerful enough to make their voices heard. Also, even if one side wishes to see major reforms (as did the unions, for example, in the beginning of the 1980s), the other side has enough veto power to block these reform attempts, in particular if supported by state actors. This was essentially the situation in the 1980s, when unions (and Social Democrats in the opposition) 
were still advocating major reforms but business and the new conservative government blocked large-scale legislative reforms and promoted cross-class compromise at the meso level instead.

\section{A New Perspective: Business as the Pivotal Actor}

As the case studies will show, both perspectives have value but fall short of explaining developments in the case of German vocational training politics. In terms of outcomes, we see neither stability (as could be expected from the VoC perspective) nor major reform (as implied in the power resource framework). Instead, we notice a pattern of incremental, transformative change (see Busemeyer 2009; Thelen and Busemeyer 2008, 2012; Trampusch 2009b, 2010 for details). With regard to politics, we do not find one dominant cleavage line but different varieties of politico-economic coalitions. Explaining both the politics and the outcomes thus requires a new theoretical approach.

The new analytical perspective that is suggested in this article builds on and expands existing approaches, largely following recent work by Kathleen Thelen and associates (Hall and Thelen 2009; Mahoney and Thelen 2010; Thelen 2004; Thelen and Busemeyer 2008, 2012). According to Thelen's coalitional or power-distribution approach, institutional change via formal policy reforms or beyond legislative policy making is driven forward by coalitions between economic actors and state actors that often run counter to the conventional left-right cleavage. At least in part driven by their erosion of membership and their general decline in influence, intermediary associations such as trade unions or employers' associations increasingly define and promote their interests in a less collectivist but more particularistic or segmentalist manner (Hassel 1999; Höpner 2007; Streeck 2009). Thus, politicoeconomic coalitions could become more short-lived in nature and based on the conjunction of interests with regard to the concrete issue at hand rather than broad ideologically motivated camps.

The case studies below show that coalitional patterns in the politics of training reform in Germany are complex and characterized by multiple, cross-cutting and intersecting cleavages that can be activated or not depending very much on the policy in question. Indeed, the traditional left-right pattern (business vs labour) depicted in classical power resource theory can hardly be found, which stands in contrast to the 1970s, when this pattern was clearly dominant (Busemeyer 2009: 79-96). Theoretical approaches in the tradition of the $\mathrm{VoC}$ approach that emphasize the importance of cross-class coalitions are better suited to explain the observed developments. In theory, we can imagine many different kinds of cross-class coalitions. Empirically (see below for details), we can identify two general types that differ with regard to whether they actively promote institutional change and reform or whether they aim to maintain existing institutional arrangements.

The first of these is a conservative cross-class coalition between unions and employers, which comes closest to the kind of insider-oriented cross-class 
coalitions prominent in the $\mathrm{VoC}$ and dualization literature (Hassel 2007; Palier and Thelen 2010). This type of coalition defends the autonomy of corporatist actors in the realm of vocational training against attempts of state actors to intervene more actively. Substantively, it aims at preserving the status quo, that is, the superior and privileged status of firm-based apprenticeship training vis-à-vis statist alternatives such as school-based vocational education. Thus, the underlying cleavage is a conflict about the extensiveness of state intrusion into the autonomy of corporatist institutions in the realm of vocational training.

The second type can be dubbed a segmentalist cross-class coalition because it aims to transform the training system towards a less collective and more firm-centred variety (see Thelen and Busemeyer 2008, 2012). This type of coalition does not square well with conventional expectations because it encompasses government actors (mainly, but not solely, from the reformist wing of the Social Democratic party) as well as business representatives. This segmentalist coalition engaged in a reform programme of gradual modernization, differentiation and flexibilization of the vocational training system. Various measures were pushed through against the vocal opposition of trade unions, although from a power resources perspective, they would be the natural allies of the social democrats in government. Also, within the camp of business, interests of large firms in the export-oriented sectors of the economy were more influential than those of small and medium-sized firms in the domestic sector.

The common element between these two types of coalitions is that business actors, in particular the interests representing medium-sized and large businesses in the export economy, are part of the dominant political coalition. This observation fits very well with the general focus of the German political economy on export industries (Hassel 2007; Thelen \& Van Wijnbergen 2003). The puzzle that requires explanation is why unions (in the case of the conservative cross-class coalition) and a social democratic government (in the case of the segmentalist coalition) decided to side with business, often ending up pitted against their natural allies.

My argument is that in different coalitions and by different means, both social democrats in government and unions try to maintain the business sector's commitment to the apprenticeship system. This puts business actors in the very powerful position of pivotal actors who can play out competing interests against each other in order to maximize their interests. They can form a conservative coalition with unions in order to defend the corporatist structure of the training regime against the intrusion of the state. But they can also engage with state actors against the opposition of unions to promote a gradual transformation and flexibilization of the training system.

Why and how does business end up in this powerful position? Conventional arguments would suggest that the privilege of business over other competing interests results from shifts in the balance of power related to exogenous forces such as economic globalization (e.g. Scharpf and Schmidt 2000). Scholars such as Lindblom (1977) have argued that the 'privileged 
position' of business is a consequence of the general structure of capitalist economies, which causes a structural dependency of the state on the willingness of private business to invest. Hacker and Pierson (2002) extend this line of reasoning by arguing that the power of business has both structural and institutional components, the latter referring to the existence of exit options for business within decentralized polities. In contrast to these arguments, I emphasize that the privileged position of business does not (necessarily) have structural foundations. Instead, it is a consequence of the specific institutional set-up of the German political economy, in which a 'semi-sovereign state' (Katzenstein 1987) is forced to rely on the co-operation of intermediary associations in policy making and implementation. Therefore, the ensuing dependency of state actors and unions on the co-operation of business is politically constructed and therefore, in principle, reversible.

More concretely, the German vocational training system is a system based on the principle of voluntary participation by individual firms. The number of available training slots cannot be set by government actors as in statist or school-based education systems. Instead, policy makers depend on the willingness of firms to offer a sufficient number of training places, and they try to provide the right incentives to enhance this willingness. Unions are incorporated into the institutional framework of the training system to a stronger extent than in other countries such as Switzerland, but they cannot force firms to offer training either. Even works councils cannot force their employers to hire apprentices; they can only make it harder for employers to fire workers already employed in the firm. The state and the unions thus have a fundamental dependence on the co-operation of business in a very concrete case: the provision of a sufficient number of training slots.

The political construction of this dependency took place roughly in the early 1980s in the form of the neocorporatist institutional compromise that emerged in the wake of the political struggles over the reform of vocational training in the 1970s. Back then, transforming the firm-oriented training system into a more statist variety reminiscent of Scandinavian education systems had been a real option, but this reform project failed, in part because employers threatened to reduce their training investments. The important outcome of these struggles was the recognition of the principle of firms' autonomy in training decisions as an important pillar of the emerging neocorporatist compromise. Unions accepted the autonomy of firms as a 'second-best' outcome, after the ambitious reforms of the 1970s had failed and a change in government from the Social Democrats to the Christian Democrats in 1982 made further large-scale reforms unlikely. In contrast to other countries such as Switzerland and Japan, where the role of unions in vocational training was already marginalized, German unions were still powerful enough to exercise considerable veto power at the industrial and the firm level. Unions were integrated into the corporatist institutional framework that was set up to make regular updates and reforms to the set of ordinances that regulated training occupations (Ausbildungsordnungen). The government promoted and supported cross-class compromise. State actors 
remained 'neutral brokers' in the background, facilitating and supporting the emergence of consensual solutions (Hilbert et al. 1990: 52; Streeck et al. 1987).

In the early 2000s, the intensification of the structural crisis on the training market paradoxically contributed to a rise of the power of business as state actors catered to the interests of business to maintain the employers' commitment to the training system. This mechanism also has a collective, that is, associational dimension that is often overlooked. Employers' associations are less able than before to enforce their individual members' compliance with collective concerns such as the provision of a sufficient number of training slots, because the associations themselves are in a process of erosion. Firms cannot be forced to provide training - neither by unions, the state, nor employers' associations - without this fundamentally challenging the corporatist deal at the core of the voluntarist system. Thus, the more firms drop out of the system, the more government actors will be willing to succumb to the demands of employers' associations to keep the remaining firms in. Employers' associations thus become more successful in lobbying for a transformation of the regulatory framework when their ability to enforce collective obligations erodes. In this sense, the organizational weakness of intermediary associations leads to political strength (Streeck 1992).

As will become clear in the case studies, business actors do not pursue a radical neoliberal reform agenda and do not support the transformation of the training system to a market-based system. This is because firms also derive concrete benefits from participating in apprenticeship training (Hassel 2007). However, the fact that firms also benefit from arrangements of collective skill formation (Busemeyer and Trampusch 2012) does not in itself ensure their continued political sustainability because individual firms always have an incentive to break out of existing institutions even though such institutions might be beneficial to employers as a whole in the long term (Streeck 2009; see also Streeck 1992). Also, while employers are unwilling to abolish the vocational training system altogether, they do have an interest in 'optimizing' the system's institutional set-up. Therefore, business actors, while maintaining their general commitment to apprenticeship training, are interested in transforming the institutional framework in such a way as to bring the training system closer in line with the individual needs of the training firms (Hassel 2007). This can be interpreted as an attempt to renegotiate the institutional settlement of the neocorporatist compromise. The goal is not to abolish the institutional framework altogether but to get rid of those institutional impositions that do not provide economic benefits.

3. Case studies: the politics of institutional change and reform in the German vocational training system

Although the German vocational training system features very prominently in the literature, there are very few studies published in English (Culpepper 
and Thelen 2008; Thelen 2004, 2007; Thelen and Busemeyer 2008, 2012; Trampusch 2009b, 2010) that have analysed the political processes behind reforms in the recent period. The following section aims to help fill this research gap by employing the method of process tracing (Hall 2006) in three case studies of recent reforms (or reform attempts) in the German vocational training system. For brevity's sake, I draw heavily here on the findings of a longer research project studying the politics of vocational training in Germany, published in German (Busemeyer 2009), which includes the insights of semi-structured interviews with more than 25 representatives of business associations (EMP), unions (UN) and state actors (ST), conducted between 2007 and 2008 (see Appendix for details). The interviews usually lasted between 60 and $90 \mathrm{~min}$. All interview partners who were initially approached agreed to talk to the author. Following requests from a majority of interview partners, I refer to the interviews in an abstract and anonymous manner.

The three cases that will be studied in the following are the introduction of two-year apprenticeships, the failed attempt to establish a training levy and the reform of the Federal Law on Vocational Education and Training. All three instances happened during the recent period (2003-2005) when a coalition of Social Democrats and Greens ${ }^{1}$ was in government.

There are two reasons this time frame and the specific cases were selected: first, the period between 2003 and 2005 was a period of high reform activity, reflecting the high level of problem pressure (lack of training slots) as well as the general political climate. In 2003, Chancellor Schröder launched a comprehensive reform agenda to overhaul the German welfare state in the fields of labour market and social policy (Agenda 2010) with major consequences (Palier and Thelen 2010; Trampusch 2009a). Some elements, in particular the reform of unemployment insurance ( Hartz IV), followed a political logic very similar to the cases studied here (see Busemeyer and Trampusch 2010 for a detailed treatment of the parallel development of welfare state and vocational training reforms). The general gist of the Agenda reform programme is also recognizable in the policy measures adopted in the field of vocational training, for example, by enhancing the linkage between training and active labour market policy (Busemeyer 2009: 158-60). The cases to be studied in detail were simply those instances in vocational training politics that generated a sizable amount of public attention. In particular, the case of the training levy was discussed at length in the public.

Second, from a theoretical perspective, it is interesting to understand the formation of unexpected politico-economic coalitions such as the segmentalist coalition between business and the social democratic government. The formation of a coalition between business interests and a conservative government would certainly be less surprising. Thus, the guiding research questions for the case studies are the following: which types of politico-economic coalitions supporting and opposing institutional change can be observed? What are the interests of relevant political actors? Which actors prevailed, and which actors lost? 


\section{The Reintroduction of Two-Year Apprenticeships}

In the core sector of the German training system in the export-oriented industry, almost all apprenticeship programmes lasted for three or three-anda-half years. Before the large-scale reform of training programmes in the metal and electrical industry in the 1980s, two-year apprenticeships were more common. In the beginning of the 1980s, however, unions changed their formerly supportive position on these two-year programmes because of concerns about firms shirking training investments (Kuda and Mignon 1982: 73). Because of the pressure of unions and works councils at the firm level, most of the old short-term training programmes were abolished and the number of apprentices in the few that survived (e.g. the Teilezurichter) had declined to a marginal level by the early 1990s (Zedler 1995). In the service sector, two-year apprenticeships were more common throughout the whole period, for example, the occupation of sales assistant (Verkäufer/in), but this did not have immediate consequences for the politics of training reform in the industrial core of the training system.

The government coalitions of Christian Democrats and Free Democrats in the 1980s and 1990s, at a rhetorical level, supported the creation of different levels of apprenticeship training (Busemeyer 2009: 119), but they did not pursue any concrete reform projects because of the strong opposition of unions. This situation changed dramatically in 2003, when Wolfgang Clement (from the Social Democratic party - SPD), then Minister for Economic and Labor Affairs, decided to decree the creation of new two-year apprenticeships, both in the service as well as in the industrial sector (Busemeyer 2009: 161, 189). What were the positions of relevant actors on this policy, and which coalitions were formed?

Employers had been arguing for a greater differentiation of the system for a long time. Instead of being forced to train all apprentices for three years or longer, they lobbied for the introduction of shorter, theoretically less demanding apprenticeships in order to avoid 'unnecessary' training investments (Busemeyer 2009: 120). Differentiating between different kinds of apprenticeships would also encourage a greater differentiation in collective wage agreements. As these agreements often linked pay groups to vocational qualifications, they forced employers to pay equal wages to workers independent of their actual productivity or the skill content of their respective jobs. For exactly these reasons, the unions were (and are) against creating different kinds of apprenticeships (Interview UN-1). They fear that the creation of less demanding types of apprenticeships will promote the further fragmentation of collective wage agreements.

The support for the new two-year apprenticeships was not universal across business sectors, however (Interview EMP-9). Large employers in the electrical and car industries were most supportive because they faced new demands for more specialized kinds of apprenticeships on the semi-skilled level below the level of the traditional skilled worker (Bellaire et al. 2006; Zeller 2007; Interviews EMP-2, EMP-4, UN-2). In contrast, firms in the 
crafts sector were quite critical (Interviews EMP-2, EMP-5). These firms' primary motivation to hire apprentices is not to secure the future supply of skilled workers but to get access to a cheap source of semi-skilled labour (Mohrenweiser and Backes-Gellner 2008). Because the productivity of apprentices increases during the latter stages of their training, these firms recoup a significant part of their training costs in the final third year and hence are less supportive of shorter apprenticeships. Furthermore, socialization into local and/or occupational communities is very important for crafts firms but usually takes longer than two years. Faced with high dropout rates from apprentices unable to meet the ever-rising demands of regular training courses, the German Chambers of Industry and Commerce (Deutscher Industrie- und Handelstag (DIHK)) chose to compromise by demanding more flexibility in setting the length of apprenticeship training for individual firms (DIHK 1999).

In contrast to employers, unions were strongly opposed to the new kind of less demanding apprenticeships. Unions feared this would promote training according to short-term needs and further weaken the commitment of firms to the apprenticeship system (DGB 2006: 52). They bitterly criticized the 'needless' break with the tradition of the consensus principle (DGB 2006: 52; Interview UN-3, UN-8), but to no avail. Another worry among the unions was that the introduction of a new kind of less demanding apprenticeship would create negative spillover effects on collective wage agreements, fragmenting them further (Busemeyer 2009: 185-6; Thelen and Busemeyer 2012). Works councils at the firm level, however, were less critical of two-year apprenticeships when faced with the alternative of hiring no apprentices. They were more willing to compromise with their respective employers in exchange for the creation of new two-year apprenticeship places, whereas union leadership at the industry level remained adamantly opposed for political reasons (Interview EMP-9).

Because new or updated occupational profiles for recognized apprenticeships are formally ministerial decrees, the minister could act against the opposition of the unions. Up until now, however, the ministry had only acted after unions and employers had reached a compromise in the respective corporatist committees. The repositioning of the government was therefore crucial for moving forward with the reform. The traditional role of the German federal government had been that of a 'neutral broker' in the background (Hilbert et al. 1990: 52), forcing and facilitating the compromise between the social partners. Now, it intervened much more actively and also broke with the traditional consensus principle. Moreover, the social democratic government, in the person of Wolfgang Clement, was acting against the unions, the Social Democrats' natural allies. Hence, the reform was not being promoted by an insider-oriented cross-class coalition but by a reform coalition of segments of business and government against the opposition of the unions and, in part, the crafts sector. It needs to be emphasized, however, that there was also conflict between the traditional left wing of the SPD in the parliamentary fraction and the reformist, business-friendly wing as 
represented by Clement. This cleavage is most important in the case of the training levy, as is discussed in the next subsection.

Why, then, did the government decide to break with the consensus principle? As said above, the social democratic government cared more about solving the persistent problem of a lack of training slots than its predecessor. By catering to the demands of employers, the government hoped to revitalize the firms' commitment to apprenticeship training. A study commissioned by the government (Vogler-Ludwig et al. 2003) came to the conclusion that the introduction of less demanding types of apprenticeships would lead to the creation of a significant number of additional training slots, in particular for young persons with low skills, who already had a hard time getting access to training. ${ }^{2}$

The crucial takeaway from this case study is that in terms of political coalitions, we can observe multiple cleavages in addition to the traditional left-right cleavage that have led to complex coalitional patterns. A first cleavage runs between large export-oriented employers and small, mediumsized firms in the domestic crafts sector. A second cleavage pits local works councils against trade unions at the industry level, although this cleavage is less salient than the first one. A third cleavage can be observed within the government coalition in the form of conflicts between traditionalists on the left and reformists on the right, although these conflicts are more relevant in the case of the training levy, as is discussed below.

\section{The Failed Attempt to Introduce a Training Levy}

Not long after the reintroduction of two-year apprenticeships, the government started a new attempt to solve the crisis on the apprenticeship market. In the fall of 2003, the parliamentary group of the Social Democrats presented a policy paper that argued in favour of introducing a training levy (SPD 2003). The revenues of this levy were to be used to subsidize firm-based apprenticeship training. The size of the levy would be computed for each firm separately, taking into account the costs of training and the individual firm's past and present commitment. The goal was to devise a policy instrument that would hurt most the firms that did not participate in training while not alienating those that stayed committed to the system.

The policy instrument of collecting a levy from non-training firms to cross-subsidize training is well established in other countries such as Denmark. Although such a levy had been a long-lasting demand of the German left, it needs to be emphasized that the SPD had always tended to regard the levy as mostly a useful political tool to encourage the voluntary participation of firms in training. In the 1970s, the governing coalition of social democrats and Free Democrats (liberals) actually passed a law that allowed the government to raise a training levy in case of a lack of training places. But the government did not use this provision in the second half of the 1970s, although the situation on the training market would have made it possible legally. The law was then declared void by the Constitutional Court 
in 1981 for reasons unrelated to the substance of the training levy (for details, see Baethge 1983; Busemeyer 2009: 88-94). The renewed interest in the training levy in the recent period should therefore primarily be regarded as a political signal from the left wing of the government coalition that more pressure should be put on employers to increase the number of available training slots. In contrast to previous proposals put forward during the 1980s and 1990s, however, this proposal came very close to being implemented despite the administrative complexities.

The training levy was a controversial subject within the SPD leadership (see for the following Busemeyer 2009: 151-7). Wolfgang Clement, a representative of the reformist, business-friendly wing, was adamantly opposed. Chancellor Schröder remained ambivalent but supported the project to appeal to the left wing of the party as a compensation for the Agenda 2010 reforms. Franz Müntefering, who was scheduled to take over the party leadership from Schröder soon, supported the levy and wanted to use it to establish himself as the new party leader. Several influential Länder ministerpresidents of the SPD opposed the training levy, threatening the governmental majority in the upper parliamentary chamber (Busemeyer 2009: 154).

The employers' associations, in coalition with the Christian Democratic and the Free Democrats' party, were strongly opposed to the training levy. They feared that the state would intrude into the autonomy that firms enjoyed in the area of apprenticeship training (KWB 2003). In contrast to the case of two-year apprenticeships, there was no cleavage between the different segments of business.

Surprisingly, unions did not support the project wholeheartedly either, although the introduction of a training levy had been a long-held demand of the unions. Left-leaning unions such as the powerful IG Metall, as well as the Confederation of German Trade Unions (DGB), supported the project. The IG BCE, a more centrist union based in the chemical, mining and energy sectors, was against it (Interview UN-6). The IG BAU, representing workers from the construction industry, also opposed the levy, although the construction sector is the only sector where a training levy had already been in use since the 1980s (Streeck et al. 1987: 26). Despite the fact that the new law gave priority to existing sectoral arrangements, the IG BAU feared that a general introduction of a training levy would endanger their successful sectoral model (Süddeutsche Zeitung, 24.3.2004: 5). ${ }^{3}$

Faced with strong opposition from within the government coalition, the unions and the employers' associations, the government decided to drop the training levy bill in the spring of 2004. Instead, it entered a 'training pact' (Nationaler Pakt für Ausbildung und Fachkräftenachwuchs in Deutschland) with employers (and without the unions). ${ }^{4}$ In this pact, which was renewed in 2007 and complemented by similar initiatives at the regional and local levels, the employers agreed to create 30,000 new apprenticeship slots every year (Ausbildungspakt 2004). Employers also committed to providing 25,000 firm-based internships per year to ease the transition into regular apprenticeship training. These internships would be subsidized by the state. 
The government and employers celebrated the pact as a success (Süddeutsche Zeitung, 5.8.2004: 19). From the perspective of the government, the threat of the more intrusive training levy had revitalized the employers' commitment to apprenticeship training. The government was happy to go along with the less intrusive and more corporatist training pact instead of being forced to push forward with the unpopular levy. Employers, of course, preferred this alternative too. Unions were critical of the pact (Financial Times Deutschland, 3.8.2005: 10), but as has already been said above, they could not bring themselves to support the training levy wholeheartedly.

What are the coalitional dynamics in the case of the training levy? At first, it seemed as if the traditional cleavage between a reform coalition of unions and the Social Democrats, on the one hand, and business and the Christian Democrats, on the other, would be revitalized. These were the political coalitions in the 1970s, when the introduction of a training levy had been discussed for the first time. During the process, however, a new coalitional dynamic set in that largely reflected the fundamental conflict between traditional and modernizing forces within the Social Democratic party and trade unions at large. The reformist wing of the Social Democrats opposed the levy and pushed for the quasi-corporatist training pact with business instead. Again, unions were not part of this coalition, although it seems as if the moderate unions such as the IG BCE would also have preferred the pact to the unpopular training levy. The left-leaning unions, which supported the levy, were entirely outside of the coalition. Interestingly, the centrist IG BCE and the left-leaning IG Metall found themselves on different sides in this conflict, although both of them can be regarded as the most likely cases of unions representing the interests of insider workers from large businesses in the export-oriented sectors of the economy.

In sum, the case of the training levy shows that the coalitional dynamics in the politics of training reform are complex. This time, the rift between promoters and opponents of reform went right through the traditional coalition of Social Democrats and unions. In the end, the employers' rhetorical threats to withdraw from offering apprenticeships were most effective in priming the government to support a quasi-corporatist training pact with few strings attached instead of pushing through with the unpopular training levy.

\section{The Reform of the Vocational Education and Training Act}

Despite the bitter conflict over the training levy, the reform of the Federal Vocational Education and Training Act (Berufsbildungsgesetz (BBiG)) passed in parliament with broad support in 2005. This case shows that the coalitions behind reforms or reform proposals can change quite suddenly and differ significantly depending on the concrete issue at hand. The case study of the reform of the BBiG also adds to the previous case studies by showing that insider-oriented cross-class coalitions can become relevant.

The $\mathrm{BBiG}$ provides a regulatory and institutional framework for the dual apprenticeship system. This framework is rather loose because, as said above, 
the content of training for individual occupations is stipulated in the form of ministerial decrees and firms offer apprenticeship training on a voluntary basis. Changing the policies of the BBiG therefore has only a limited impact on the actual transformation of the system. What is more, vocational training politics is a policy field with a large number of veto players. In addition to the federal government, unions and employers' associations, the Länder governments have a seat at the table because they are responsible for the school-based portions of dual training. Therefore, although it was the most significant reform in vocational training since the early 1980s, the reform of the BBiG in 2005 was widely regarded as an incremental step rather than a radical policy reform (Greinert 2005).

In spite of this, the reformed $\mathrm{BBiG}$ contained a number of important changes. For example, the law aimed to improve the link between the various measures of the transition system, active labour market policies and regular training, as well as to open up the German system to international exchange. In the context of the present article, the most important change was the decision to establish a school-based alternative track alongside firm-based training. School-based vocational education and training (VET) in Germany has traditionally been focused on professions in the health and social sectors (and dominated by young women). There was no occupational or professional overlap between the dual training system and school-based VET because policy makers and stakeholders wanted to avoid a direct competition between school-based and firm-based training. The 2005 reform changed this situation. In order to deal with the structural crisis in the market for apprenticeships, the law envisaged the establishment of a school-based alternative track to regular dual training by admitting students of vocational schools to the final exams administered by the Chambers of Industry and Commerce. Apprentices from firm-based and school-based training schemes alike would thus end up with the same vocational qualification in the end.

The establishment of a school-based alternative track to regular dual training could have benefited educational outsiders. A similar reform was enacted in Denmark in the early 1990s, and as a consequence of this, Denmark now fares better than Germany in mitigating youth unemployment and integrating educational outsiders (Martin and Knudsen 2010; Nelson 2012). In Germany, those captured in the 'holding patterns' of the transition system cannot acquire vocational qualifications with any real labour market recognition. In contrast, students in the envisaged school-based VET track would end up with the same vocational degree as regular apprentices, although the latter would probably still have an easier time moving from training to employment. As a corollary to the improvement of the position of education outsiders, the relative position of the current insiders would deteriorate. This is most evident when looking at the policy positions of relevant stakeholders: the state, employers and unions.

The state's policy position was determined when the Christian Democrats sided with the government coalition of Social Democrats and Greens in supporting the bill. Although the law contained the previously mentioned 
proposal to establish a school-based alternative track, the accompanying statement by the parliamentary fractions proclaimed that the purpose of the law was to 'stop the trend of strengthening the role of the state [Verstaatlichung] in vocational training' (Fraktionen 2004: 2-3). This paradoxical statement shows that policy makers were not aiming for a full-scale transformation of the system along Danish lines. Instead, the establishment of a school-based track was supposed to be a temporary measure to ease the pressure on the market for apprenticeships, and the relevant provision in the law contained a sunset clause: it was scheduled to run out in 2011.

Employers were openly opposed to establishing the school-based alternative track (Interview EMP-9). They feared it would strengthen the role of vocational schools and the state in general in vocational training and enhance the competition between school-based and firm-based training schemes, which would eventually have a negative impact on the autonomy of training firms and their willingness to participate in apprenticeship training (Esser 2006). In contrast to their behaviour in the previously discussed cases, here most unions sided with the employers in their opposition against the schoolbased alternative track (DGB 2004: 6). From the unions' perspective, dual training was superior to school-based VET in integrating young people into the labour market (DGB 2004: 44; IG BCE 2007: 37-38; Interview UN-6). Only the Gewerkschaft Erziehung und Wissenschaft - the teachers' union supported the expansion of school-based training (Kreft 2006: 259).

Unions and employers' associations also worked together to slow down the implementation of the school-based training provision. During the decision-making process, unions and employers successfully demanded that they be strongly involved in deciding which school-based training schemes would be accredited (DGB 2005: 6; Kremer 2006: 15). School-based VET falls into the domain of the German Länder, or federal states, and decisions on it must therefore be made separately for each Land, which amplifies the veto power of the social partners. Because the school provision is set to run out in 2011, it is highly unlikely that it will lead to a systematic transformation that would establish a viable school-based track.

In sum, the case of the reform of the BBiG shows that insider-oriented cross-class coalitions are also an important element in the politics of training reform. A coalition between the majority of unions and employers' associations has effectively blocked the implementation of a policy reform that could have benefited educational outsiders. State actors of various political stripes, however, have implicitly supported this coalition. They only showed halfhearted support for the establishment of a school-based alternative track in the first place, signalling early on that a full-scale transformation of the system was not intended.

\section{Conclusions and outlook}

This article has argued that cross-class coalitions are the dominant political force in the politics of reforming the German vocational training system. 
However, the case studies have shown that there are different varieties of cross-class coalitions, which I have called conservative and segmentalist cross-class coalitions. The somewhat unexpected occurrence of a social democratic government allying with business against an opposition made up of their natural allies - the unions - prompted a more thorough rethinking of the role of business in the politics of training reform. I have argued that this alliance can best be understood if one recognizes the fundamental dependence of policy makers on the willingness and ability of firms to provide a sufficient number of training places. This dependence is not structural but stems from the specific institutional set-up of the German vocational training system based on the principles of voluntarism and firm autonomy. The political consequence of this institutional set-up is to put business in a very powerful position as a pivotal actor. The outcome of recent reforms is an incremental, but in the long-term transformative change of the system towards a more flexible, firm-centred variety (Thelen and Busemeyer 2008, 2012).

What is the likely impact of this transformation on the apprenticeship market? Most importantly, the transition system continued to expand during the reign of the SPD-Green coalition, although the situation on the training market improved somewhat after the period studied in this article. How much of this development may be due to exogenous forces, such as the economic upswing in 2006-2007 or a declining number of school leavers, on the one hand, and the effect of government reforms, on the other, is hard to judge. Nevertheless, it can be said that the number of young people in the transition system remains significant. Therefore, the long-term rise of the transition system resonates very well with the recent debate on the dualization of co-ordinated market economies (Eichhorst and Marx 2010; Iversen 2005; King and Rueda 2008; Palier and Thelen 2010). From this perspective, the transition system represents a new kind of secondary training market within the dual training system because it represents an additional gateway in the transition from school to training and employment. For some apprenticeship applicants, the transition system might help to improve their skill set. The existing empirical evidence suggests, however, that the transition system is not very effective in mitigating educational deficiencies of low-skilled youth and thus simply extends the transition period between school and training (Baethge et al. 2007; Beicht 2009; Bellaire et al. 2006).

Given these ambiguities, the real impact of reforms or missed reform opportunities on the training system is hard to assess, but more ambitious reforms for large-scale institutional change would have been a stronger antidote against dualization. Examples would be the establishment of a levy-grant system whose revenues could have been used to sponsor out-of-firm training or to subsidize training in small firms or the institutionalization of a fullyfledged school-based alternative track. These and other policies have been introduced in other countries, such as Austria and Denmark (Graf et al.2012; Martin and Knudsen 2010; Nelson 2012), and have proven to be quite successful in fighting youth unemployment and labour market stratification. 
In Germany, by contrast, the outcome can best be described as dualization by drift. ${ }^{5}$ No relevant political stakeholder would openly promote dualization, but the alternating dominance of either the conservative or the segmentalist cross-class coalition has been effective in blocking the kind of large-scale policy and institutional change that would have been (and still is, by the way) necessary to effectively counter the ongoing trend towards dualization. The conservative cross-class coalition blocked attempts to institutionalize fully-fledged school-based alternatives that would probably have been more effective in countering the trend towards dualization. ${ }^{6}$ The segmentalist coalition did promote incremental reforms, but these reforms were primarily aimed at flexibilizing the system. Although the government hoped this reform of the training system would boost employers' willingness to increase the supply of training places, this aspect was subordinated to the goal of modernizing the system. Thus, in the end, I concur with Palier and Thelen (2010: 126, 131), who argue that dualization should be regarded as an unintended consequence of enhanced (or maintained) co-operation in the form of cross-class coalitions.

The new element this article brings into the debate is to highlight the pivotal role of business actors in the politics of training reform, which has enormous implications for understanding the nature of business power and has not been recognized in the pertinent literature yet. For example, Hacker and Pierson (2002) claim that business prevails because business actors have more resources at their disposal. But in the German case, the membership base of business associations is eroding (Hassel 1999; Streeck 2009), and financial contributions to political parties are less important than in the political system of the United States. Recent work by Culpepper (2010) suggests that business influence is strongest on issues that are not discussed in public, and vocational training is usually a good example of a field of 'quiet politics'. The case studies in this article, in particular the case of the training levy, have shown that training reforms are highly debated in the public, however. Therefore, Culpepper's argument about the strong influence of business behind the scenes cannot help us to fully understand why business prevailed in these conflicts. Instead, in the cases studied above, the power of business stems from its pivotal position in the corporatist decision-making arena.

What are the implications of the findings of this article beyond the concrete case at hand? First of all, there is some evidence that the political dynamic of recent reforms in the field of VET can be observed in other policy fields as well, in particular social policy (Busemeyer and Trampusch 2010; Häusermann 2010). Future research should also try to reveal whether business actors occupy a pivotal position in other countries as well. In my view, the extent to which the mechanism also works in countries with more fragmented and pluralist industrial relations (such as the United Kingdom) is debatable. The pivotal position of business - and, in particular, business associations - stems from the particular institutional and political set-up of the corporatist cross-class compromise. Nevertheless, it would be highly interesting to 
see whether business actors in liberal market economies as well are increasingly in a position to maximize their interests by entering different coalitions with unions and state actors.

\section{Acknowledgements}

I would like to thank Anke Hassel, Silja Häusermann, Ronen Mandelkern, Cathie Jo Martin, Wolfgang Streeck, Kathleen Thelen and Christine Trampusch as well as two anonymous reviewers and the editors of the BJIR for very helpful comments and suggestions on previous versions of this article. I would also like to thank Astrid Dünkelmann and Casey Butterfield for their help with language editing.

\section{Notes}

1. The German Green party has its roots in the anti-nuclear and peace movement of the 1980s. With regard to social policy, its position is very close to the social democrats, albeit less statist and more liberal.

2. Although the number of apprentices in two-year occupations increased by almost 50 per cent between 2004 and 2008, the overall supply of training places remained relatively constant (Thelen and Busemeyer 2012: 83). This is initial evidence that the reform contributed to a restructuring of the supply of training instead of the creation of additional training opportunities.

3. An additional reason might have been that the levy-scheme is voluntary in the construction industry (as it is based on collective agreements between the social partners), whereas the new levy would have been compulsory.

4. Formally, the new Ausbildungspakt is not connected to the previous Bündnis für Arbeit, although there are obvious political connections. A crucial difference is that unions fully participated in the Bündnis für Arbeit.

5. I thank Kathleen Thelen for pointing this out to me.

6. However, it needs to be emphasized that the commonly held view among unions is that firm-based training is the best instrument against youth unemployment and performs much better than school-based alternatives (DGB 2004, 2006).

\section{References}

Anderson, K. M. and Hassel, A. (2007). 'Pathways of Change in CMEs: Training Regimes in Germany and the Netherlands'. Paper prepared for the American Political Science Association Meeting, Chicago, 27 August-1 September 2007.

Ausbildungspakt (2004). Nationaler Pakt für Ausbildung und Fachkräftenachwuchs in Deutschland. Berlin: Federal Ministry for Economic and Labor Affairs.

Autorengruppe BIBB and Bertelsmannstiftung (2011). Reform des Übergangs von der Schule in die Berufsausbildung: Aktuelle Vorschläge im Urteil von Berufsbildungsexperten und Jugendlichen. Bonn, Gütersloh: BIBB, Bertelsmannstiftung. 
Baethge, M. (1983). 'Berufsbildungspolitik in den siebziger Jahren: Eine Lektion in ökonomischer Macht und politischer Ohnmacht'. In A. Lipsmeier (ed.), Berufsbildungspolitik in den 70er Jahren. Eine kritische Bestandsaufnahme für die 80er Jahre (Beiheft 4 zur Zeitschrift für Berufs- und Wirtschaftspädagogik), Wiesbaden: Steiner, pp. $145-57$.

— Solga, H. and Wieck, M. (2007). Berufsbildung im Umbruch: Signale eines überfälligen Aufbruchs. Berlin: Friedrich-Ebert-Stiftung.

Beicht, U. (2009). 'Verbesserung der Ausbildungschancen oder sinnlose Warteschleife? Zur Bedeutung und Wirksamkeit von Bildungsgängen am Übergang Schule - Berufsausbildung'. BWP-Report, 11: 1-16.

Bellaire, E., Brandes, H., Friedrich, M. and Menk, A. (2006). Zweijährige Ausbildungsgänge: Eine Chance für Jugendliche mit schlechten Startchancen? Betriebsbefragungen zu neuen Berufen. Bielefeld: W. Bertelsmann Verlag.

Bradley, D., Huber, E., Moller, S., Nielsen, F. and Stephens, J. D. (2003). 'Distribution and redistribution in postindustrial democracies'. World Politics, 55: 193-228.

Busemeyer, M. R. (2009). Wandel trotz Reformstau: Die Politik der beruflichen Bildung seit 1970. Frankfurt am Main: Campus.

- and Trampusch, C. (2010). 'Liberalization by Exhaustion: Transformative Change in the German Welfare State and Vocational Training System'. Paper presented at the Conference of the Council of European Studies, Montreal, April.

and (eds.) (2012). The Political Economy of Collective Skill Formation. Oxford: Oxford University Press.

Crouch, C., Finegold, D. and Sako, M. (1999). Are Skills the Answer? The Political Economy of Skill Creation in Advanced Industrial Countries. Oxford: Oxford University Press.

Culpepper, P. D. (1999). 'Still a model for the industrialized countries?' In P. D. Culpepper and D. Finegold (eds.), The German Skills Machine: Sustaining Comparative Advantage in a Global Economy. Oxford: Berghahn Books, pp. 134.

(2010). Quiet Politics and Business Power: Corporate Control in Europe and Japan. Cambridge: Cambridge University Press.

- and Thelen, K. (2008). 'Institutions and collective actors in the provision of training: historical and cross-national comparisons'. In K.-U. Mayer and H. Solga (eds.), Skill Formation: Interdisciplinary and Cross-National Perspectives. Cambridge: Cambridge University Press, pp. 21-49.

Cusack, T. R., Iversen, T. and Soskice, D. (2007). 'Economic interests and the origins of electoral systems'. American Political Science Review, 101: 373-91.

DGB (2004). Reform der Berufsbildung. Berlin: DGB-Bundesvorstand.

- (2005). Berufsbildungsreformgesetz (BerBiRefG): Bewertung des DGB. Berlin: DGB-Bundesvorstand.

— (2006). Beschlüsse zur Bildungspolitik: 18. Ordentlicher DGB Bundeskongress, 22.-26.05.2006. Berlin: DGB-Bundesvorstand.

DIHK (1999). Leitlinien Ausbildungsreform: Wege zu einer modernen Beruflichkeit. Bonn: DIHK.

Eichhorst, W. and Marx, P. (2010). 'Whatever Works: Dualisation and the Service Economy in Bismarckian Welfare States'. IZA Discussion Paper No. 5035.

Esser, F. H. (2006). 'Vollzeitschulische Berufsausbildung: Bedrohung oder Herausforderung für das duale System?' In A. Zöller (ed.), Vollzeitschulische Berufsausbildung: Eine gleichwertige Partnerin des dualen Systems? Bielefeld: W. Bertelsmann Verlag, pp. 91-98. 
Estévez-Abe, M., Iversen, T. and Soskice, D. (2001). 'Social protection and the formation of skills: a reinterpretation of the welfare state'. In P. A. Hall and D. Soskice (eds.), Varieties of Capitalism: The Institutional Foundations of Comparative Advantage. Oxford: Oxford University Press, pp. 145-83.

Finegold, D. and Soskice, D. (1988). 'The failure of training in Britain: analysis and prescription'. Oxford Review of Economic Policy, 4: 21-53.

Fraktionen (2004). Entschließungsantrag der Fraktionen von SPD, CDU/CSU und BÜNDNIS 90/Die GRÜNEN im Ausschuss für Bildung, Forschung und Technikfolgenabschätzung zum Gesetzentwurf der Bundesregierung: Entwurf eines Gesetzes zur Reform der beruflichen Bildung (Bundestags-Drucksache 15/3980). Berlin: Deutscher Bundestag.

Graf, L., Lassnigg, L. and Powell, J. J. W. (2012). 'Austrian corporatism and institutional change in the relationship between apprenticeship training and school-based VET'. In M. R. Busemeyer and C. Trampusch (eds.), The Political Economy of Collective Skill Formation. Oxford: Oxford University Press, pp. 150 78.

Green, A. (2001). 'Models of high skills in national competition strategies'. In P. Brown, A. Green and H. Lauder (eds.), High Skills: Globalization, Competitiveness, and Skill Formation. Oxford: Oxford University Press, pp. 56-160.

Greinert, W.-D. (2005). 'Warum in der Bundesrepublik ein modernes Berufsbildungsrecht nicht durchsetzbar ist - kritische Anmerkungen zur aktuellen Reformpolitik'. In K. Büchter (ed.), Berufspädagogische Erkundungen — Eine Bestandsaufnahme in verschiedenen Forschungsfeldern. Frankfurt am Main: Verlag der Gesellschaft zur Förderung arbeitsorientierter Forschung und Bildung (GFAB), pp. 195-210.

Hacker, J. S. and Pierson, P. (2002). 'Business power and social policy: employers and the formation of the American welfare state'. Politics \& Society, 30: 277-326.

Hall, P. A. (2006). 'Systematic process analysis: when and how to use it'. European Management Review, 3: 24-31.

— and Soskice, D. (2001). 'An introduction to varieties of capitalism'. In P. A. Hall and D. Soskice (eds.), Varieties of Capitalism: The Institutional Foundations of Comparative Advantage. Oxford: Oxford University Press, pp. $1-68$.

— and Thelen, K. (2009). 'Institutional change in varieties of capitalism'. SocioEconomic Review, 7: 7-34.

Hassel, A. (1999). 'The erosion of the German system of industrial relations'. British Journal of Industrial Relations, 37: 483-505.

- (2007). 'What does business want? Labour market reforms in CMEs and its problems'. In B. Hancké, M. Rhodes and M. Thatcher (eds.), Beyond Varieties of Capitalism: Conflict, Contradictions, and Complementarities in the European Economy. Oxford: Oxford University Press, pp. 253-77.

Häusermann, S. (2010). 'Solidarity with whom? Why organised labour is losing ground in Continental pension politics'. European Journal of Political Research, 49: 22356.

Hilbert, J., Südmersen, H. and Weber, H. (1990). Berufsbildungspolitik: GeschichteOrganisation-Neuordnung. Opladen: Leske + Budrich.

Höpner, M. (2007). 'Coordination and Organization: The Two Dimensions of Nonliberal Capitalism'. MPIfG Discussion Paper 07/12.

IG BCE (2007). Offensive: Bildung: Grundsätze, Handlungsfelder, Empfehlungen. Hannover: IG BCE, Abteilung Bildung/Weiterbildung. 
Iversen, T. (2005). Capitalism, Democracy, and Welfare. Cambridge: Cambridge University Press.

Katzenstein, P. J. (1987). Policy and Politics in West Germany: The Growth of a Semi-Sovereign State. Philadelphia, PA: Temple University Press.

King, D. and Rueda, D. (2008). "Cheap labor: the new politics of "bread and roses" in industrial democracies'. Perspectives on Politics, 6: 279-97.

Kitschelt, H. (1999). 'European social democracy between political economy and electoral competition'. In H. Kitschelt, P. Lange, G. Marks and J. D. Stephens (eds.), Continuity and Change in Contemporary Capitalism. Cambridge: Cambridge University Press, pp. 317-45.

Korpi, W. (1983). The Democratic Class Struggle. London: Routledge.

Kreft, J. (2006). Gewerkschaften und Spitzenverbände der Wirtschaft als bildungspolitische Akteure: Positionen, Strategien und Allianzen. Wiesbaden: VS Verlag für Sozialwissenschaften.

Kremer, M. (2006). 'Implikationen der BBiG-Novelle auf die Kooperation von Schule und Betrieb in der Berufsausbildung'. In A. Zöller (ed.), Vollzeitschulische Berufsausbildung: Eine gleichwertige Partnerin des dualen Systems? Bielefeld: W. Bertelsmann Verlag, pp. 7-35.

Kuda, E. and Mignon, U. (1982). Berufliche Bildung: Situation Konflikte Lösungen. Köln: Bund-Verlag.

KWB (2003). Ausbildungsabgabe: Schaden statt Nutzen, Neue Probleme statt Lösungen. Bonn: Kuratorium der Deutschen Wirtschaft für Berufsbildung.

Lindblom, C. E. (1977). Politics and Markets: The World's Political-Economic Systems. New York: Basic Books.

Mahoney, J. and Thelen, K. (2010). 'A theory of gradual institutional change'. In J. Mahoney and K. Thelen (eds.), Explaining Institutional Change: Ambiguity, Agency, and Power. Cambridge: Cambridge University Press, pp. 1-37.

Martin, C. J. and Knudsen, J. S. (2010). 'Scenes from a mall: retail training and the social exclusion of low-skilled workers'. Regulation \& Governance, 4: 345-64.

Mohrenweiser, J. and Backes-Gellner, U. (2008). 'Apprenticeship Training: What for? Investment in Human Capital or Substitution of Cheap Labour?' Swiss Leading House on the Economics of Education Working Paper No. 17.

Nelson, M. (2012). 'Continued collectivism: the role of trade self-management and the social democratic party in Danish vocational education and training'. In M. R. Busemeyer and C. Trampusch (eds.), The Political Economy of Collective Skill Formation. Oxford: Oxford University Press, pp. 179-204.

Palier, B. and Thelen, K. (2010). 'Institutionalizing dualism: complementarities and change in France and Germany'. Politics \& Society, 38: 119-48.

Rothstein, B. (1987). 'Corporatism and reformism: the social democratic institutionalization of class conflict'. Acta Sociologica, 30: 295-311.

Scharpf, F. W. and Schmidt, V. A. (eds.) (2000). Welfare and Work in the Open Economy: From Vulnerability to Competitiveness, Volume I. Oxford: Oxford University Press.

Silvia, S. J. and Schroeder, W. (2007). 'Why are German employers associations declining? Arguments and evidence'. Comparative Political Studies, 40: 143359.

SPD (2003). Eckpunkte Ausbildungsfinanzierung: Eine gute Zukunft durch Ausbildung für alle! Berlin: SPD-Bundestagsfraktion.

Stephens, J. D. (1979). The Transition from Capitalism to Socialism. London: Macmillan. 
Streeck, W. (1992). 'On the institutional conditions of diversified quality production'. In W. Streeck and E. Matzner (eds.), Beyond Keynesianism: The Socio-Economics of Production and Full Employment. Cheltenham: Edward Elgar, pp. 21-61.

(2009). Re-Forming Capitalism: Institutional Change in the German Political Economy. Oxford: Oxford University Press.

— und Regulierung der beruflichen Bildung: Die Rolle der Sozialpartner in der Ausbildung und beruflichen Weiterbildung in der Bundesrepublik Deutschland. Berlin: edition sigma.

Thelen, K. (2004). How Institutions Evolve: The Political Economy of Skills in Germany, Britain, the United States and Japan. Cambridge: Cambridge University Press.

(2007). 'Contemporary challenges to the German vocational training system'. Regulation \& Governance, 1: 247-60.

— and Busemeyer, M. R. (2008). 'From Collectivism towards Segmentalism: Institutional Change in German Vocational Training'. MPIfG Discussion Paper $08 / 13$.

— and (2012). 'Institutional change in German vocational training: from collectivism toward segmentalism'. In M. R. Busemeyer and C. Trampusch (eds.), The Political Economy of Collective Skill Formation. Oxford: Oxford University Press, pp. 68-100.

and Van Wijnbergen, C. (2003). 'The paradox of globalization: labor relations in Germany and beyond'. Comparative Political Studies, 36: 859-80.

Trampusch, C. (2009a). Der erschöpfte Sozialstaat: Transformation eines Politikfeldes. Frankfurt am Main: Campus.

(2009b). 'Europeanization and institutional change in vocational education and training in Germany and Austria'. Governance, 22: 371-97.

(2010). 'Employers, the state and the politics of institutional change: vocational education and training in Austria, Germany and Switzerland'. European Journal of Political Research, 49: 545-73.

Ulrich, J. G. (2006). 'Wie groß ist die "Lehrstellenlücke" wirklich? Vorschlag für einen alternativen Berechnungsmodus'. BWP, 3/2006: 12-16.

Vogler-Ludwig, K., Düll, N., Leitzke, S. and Letzner, V. (2003). Ausbildung für einfache Berufe: Identifizierung von Tätigkeitsfeldern mit weniger komplexen Anforderungen als Basis zur Schaffung neuer anerkannter Ausbildungsberufe mit abgesenktem Anforderungsniveau: Kurzfassung des Endberichts, Gutachten für das Bundesministerium für Wirtschaft und Arbeit. München: Economix Research \& Consulting.

Wagner, K. (1999). 'The German apprenticeship system under strain'. In P. D. Culpepper and D. Finegold (eds.), The German Skills Machine: Sustaining Comparative Advantage in a Global Economy. Oxford: Berghahn Books, pp. 3776.

Zedler, R. (1995). 'Zweijährige Ausbildungsberufe in der Metall-Industrie'. IBVInformationen, 49: 4333-5.

Zeller, B. (2007). 'Neue Qualifikationsanforderungen an der Schnittstelle von einfacher Arbeit und Facharbeit am Beispiel der Elektroindustrie'. In H. Dietrich and E. Severing (eds.), Zukunft der dualen Berufsausbildung — Wettbewerb der Bildungsgänge, Schriften zur Berufsbildungsforschung der Arbeitsgemeinschaft Berufsbildungsforschungsgesetz ( $A G B F N$ ). Bielefeld: W. Bertelsmann Verlag, pp. 61-82. 


\section{Appendix: Overview of interview partners}

The case studies are in part based on the insights from 25 semi-structured background interviews with representatives from the state, business associations and trade unions. The following table contains details on the interview partners.

\begin{tabular}{|c|c|}
\hline Sector & $\begin{array}{l}\text { Interview partner } \\
\text { Representative of } \ldots\end{array}$ \\
\hline State & $\begin{array}{l}\text { Federal Ministry of Education and Research (Bundesministerium für Bildung } \\
\text { und Forschung, BMBF) } \\
\text { Federal Institute for Vocational Education and Training (Bundesinstitut für } \\
\text { Berufsbildung, BIBB) }\end{array}$ \\
\hline Employers & $\begin{array}{l}\text { German Association of Employers (Bundesvereinigung der Deutschen } \\
\text { Arbeitgeberverbände, BDA) } \\
\text { Association of German Craft Industry (Zentralverband des Deutschen } \\
\text { Handwerks, ZDH) } \\
\text { Association of employers in the metal industry (Gesamtmetall) and regional } \\
\text { branch (Südwestmetall) } \\
\text { Association of employers in the construction industry (Hauptverband Deutsche } \\
\text { Bauindustrie) } \\
\text { Association of employers in construction crafts (Zentralverband Deutsches } \\
\text { Baugewerbe, ZDB) } \\
\text { Board of Trustees of German Business for Vocational Education and Training } \\
\text { (Kuratorium der Deutschen Wirtschaft für Berufsbildung, KWB) } \\
\text { Association of Bavarian Machine-Building Industry (Verband der Bayerischen } \\
\text { Metall- und Elektroindustrie, VBM) } \\
\text { Associaton of German Machine-Building Industry (Verband Deutscher } \\
\text { Maschinen- und Anlagenbau, VDMA) } \\
\text { Association of German Electrical and Electronics Industry (Zentralverband } \\
\text { Elektrotechnik- und Elektronikindustrie, ZVEI) } \\
\text { Representatives of large German employers in the automotive and chemical } \\
\text { industries }\end{array}$ \\
\hline Unions & $\begin{array}{l}\text { Confederation German Trade Unions (Deutscher Gewerkschaftsbund, DGB) } \\
\text { United Services Union (Vereinte Dienstleistungsgewerkschaft, ver.di) } \\
\text { Industrial Union of Metalworkers (IG Metall) } \\
\text { Hans Böckler Foundation } \\
\text { Industrial Union in Construction Industry (IG Bauen-Agrar-Umwelt, IG BAU) } \\
\text { Industrial Union in Chemical Industry and Mining (IG Bergbau, Chemie, } \\
\quad \text { Energie, IG BCE) } \\
\text { Education and Science Workers' Union (Gewerkschaft Erziehung und } \\
\quad \text { Wissenschaft, GEW) }\end{array}$ \\
\hline
\end{tabular}

